\title{
PENGARUH PARTISIPASI ANGGARAN TERHADAP KINERJA MANAJERIAL DENGAN PERSEPSI KEADILAN ANGGARAN DAN KOMITMEN TUJUAN ANGGARAN SEBAGAI VARIABEL INTERVENING (Studi Kasus pada Universitas Diponegoro)
}

\author{
Hanifatuz Zahro \\ Indira Januarti
}

Jurusan Akuntansi

Fakultas Ekonomika dan Bisnis, Universitas Diponegoro

\begin{abstract}
This study aims to examine the influence of budget participation to managerial performance. It also to examine whether perception of distribution budgetary fairness, perception of procedural budgetary fairness and goal commitment mediate the relationship of budget participation and managerial performance.This study used questionnaires and interview to collecting data. From 189 questionnaires were given to managers in Diponegoro University. The questionnaires that complete the answers were 72 questionnaires. Path analysis was utilized to examine the direct and indirect effects of budget participatio to managerial performance. The results of this study showed that budget participation has a direct effect to managerial performance. Budget participation also has a positive effect to perception of distribution budgetary fairness, perception of procedural budgetary fairness and goal commitment. But budget participation didn't has indirect effect to managerial performance with perception of distribution budgetary fairness, perception of procedural budgetary fairness and goal commitment as intervening variables.
\end{abstract}

Keywords: Budget participation, managerial performance, perception of distribution budgetary fairness, perception of procedural budgetary fairness, goal commitment

PENDAHULUAN

Banyaknya perguruan tinggi

saat ini, baik negeri maupun swasta membuat mereka berlomba-lomba untuk mempromosikan dirinya bahwa mereka dapat mencetak lulusan terbaik dan juga memberikan pelayanan serta fasilitas yang baik.
Untuk dapat mencapai hal tersebut, maka perguruan tinggi perlu mengolah sumber daya dan menciptakan sistem manajerial yang baik. Dengan sumber daya yang dimiliki, perguruan tinggi harus memberikan jasa pelayanan pendidikan terbaik secara langsung maupun tidak langsung. Hal itu 
menyebabkan perlunya fungsi manajerial dan keterampilan manajemen yang baik terkait sumber daya.

Perbedaan perguruan tinggi negeri dan swasta adalah perguruan tinggi negeri mendapatkan dana dari pemerintah yang dianggarkan dalam APBN. Hal tersebut menyebabkan perguruan tinggi negeri sebagai instansi pemerintah dalam penerapan anggarannya harus berbasis kinerja sesuai dengan UU No 17 Tahun 2003 tentang Keuangan Negara dan ditetapkan secara bertahap mulai tahun anggaran 2005.

Dalam mencapai efektivitas dan efisiensi organisasi, maka diperlukan kinerja manajerial yang baik (Sumadiyah dan Susanta, 2004). Kinerja manajerial yang baik dapat dilihat indikatornya dari bagaimana manajer menjalankan fungsi manajemen (Giri, 2014). Menurut Handoko (1996:34) fungsi manajemen terdiri dari perencanaan, investigasi, pengkoordinasian, evaluasi, pengawasan, pemilihan staf, negosiasi, dan perwakilan.

$$
\text { Menjalankan fungsi-fungsi }
$$

manajemen yang baik oleh perguruan tinggi, tidak hanya mencapai efektivitas dan efisiensi organisasi tetapi juga meningkatkan mutu, produktivitas, dan inovasi (Qiftiyah, 2015). Untuk menilai apakah perguruan tinggi memiliki mutu yang baik, pemerintah menetapkan standar bagi perguruan tinggi yang biasa disebut akreditasi perguruan tinggi. Akreditasi merupakan pengakuan dan penilaian mengenai suatu lembaga pendidikan tentang kelayakan dan kinerja yang dilakukan oleh Badan Akreditasi Nasional Perguruan Tinggi atau BAN-PT (Qiftiyah, 2015). Menurut Keputusan Menteri Pendidikan Nasional Nomor 087/U/2002, salah satu tujuan akreditasi adalah mendapatkan gambaran mengenai kinerja lembaga pendidikan sebagai alat pembinaan, pengembangan, dan peningkatan mutu.

$$
\text { Terdapat tujuh standar }
$$
penilaian akreditasi perguruan tinggi. Dari tujuh standar tersebut, terdapat elemen yang dinilai seperti partisipasi pemangku kepentingan dalam menyusun rencana strategis, melaksanakan fungsi-fungsi manajemen, serta pembiayaan yang merupakan usaha dalam menyediakan, mengelola dan meningkatkan mutu anggaran yang memadai untuk mendukung penyelenggaraan 
program-program akademik yang prestasi mereka dan kemungkinan bermutu di perguruan tinggi sebagai lembaga nirlaba. Artinya, akreditasi mendorong perguruan tinggi untuk meningkatkan kinerja manajerial salah satunya dengan cara partisipasi anggaran, sehingga perguruan tinggi dapat juga meningkatkan mutu, efektivitas, efisiensi, produktivitas, dan inovasi.

Kurnia (2010) berpendapat bahwa untuk mencapai keefektifan kinerja manajerial diperlukan partisipasi penyusunan anggaran oleh bawahan dan tujuan anggaran tercapai. Dengan keikutsertaannya bawahan dalam partisipasi anggaran akan meningkatkan kinerja manajerial karena terdapat komunikasi sehingga bawahan dapat memilih, pilihannya tersebut merupakan tanggung jawab dalam dirinya akibat keterlibatan dalam penyusunan anggaran sehingga menguatkan komitmen dan meningkatkan kinerja (Herimawati, 2013).

Dalam partisipasi anggaran melibatkan individu-individu secara langsung, dimana individu-individu tersebut memliki pengaruh dalam tujuan penyusunan anggaran. Bawahan yang terlibat dalam menyusun anggaran akan dinilai diberikan penghargaan dalam pencapaian tujuan anggaran mereka (Brownell, 1982). Hal itu dapat memberikan dampak terhadap peningkatan kinerja manajerial yang akhirnya dapat meningkatkan efektivitas organisasi (Nor, 2007).

Banyak penelitian yang meneliti hubungan partisipasi anggaran dengan kinerja manajerial. Hasil dari peneltian tersebut tidak selamanya konsisten dan bervariasi. Penelitian yang dilakukan oleh Kamilah et al (2012), Budiman et al (2013), Halik (2013), Putra et al (2014) menemukan hasil bahwa partisipasi anggaran berpengaruh positif terhadap kinerja manajerial. Terdapat hasil penelitian yang berbeda yang dilakukan oleh Hafridebri (2013), serta Medhayanti dan Suardhana (2015) bahwa partisipasi anggaran berpengaruh negatif terhadap kinerja manajerial. Terdapat alasan mengapa partisipasi anggaran berpengaruh secara negatif, yaitu perilaku disfungsional partisipan, misalnya penetapan standar yang terlalu tinggi atau rendah, kesenjangan anggaran (budgetary slack), partisipasi semu, yaitu partisipasi yang dilakukan hanya partisipasi palsu (Hansen dan 
Mowen, 2009). Siegel dan Marconi (1989) menyatakan bahwa partisipasi semu membuat bawahan tidak memiliki motivasi untuk melaksanakan tujuan organisasi secara maksimal.

Anthony dan Govindarajan (2005) mengemukakan bahwa terdapat faktor-faktor lain yang bersifat kontingensi atas ketidakkonsistensian tersebut. Ketidakkonsistensian hasil penelitian tersebut memunculkan kemungkinan bahwa terdapat variabelvariabel lain, seperti variabel intervening atau moderasi yang dapat mempengaruhi hubungan variabel independen dengan variabel dependen (Nor, 2007). Penelitian-penelitian terdahulu banyak mengindikasikan bahwa persepsi keadilan anggaran dan komitmen terhadap tujuan anggaran sebagai variabel pemediasi.

Wentzel

(2002)

telah

menggunakan

Variabel-variabel

sebagai variabel pemediasi antara partisipasi angggaran dengan kinerja manajerial pada rumah sakit di Amerika Serikat yang pada saat itu sedang terjadi pemotongan anggaran. Leventhal (1980) mendefinisikan keadilan distributif sebagai kepercayaan terhadap individu bahwa segala sesuatu hal yang diterima oleh karyawan baik itu upah, hukuman atau sumber daya telah adil didistribusikan sesuai dengan kriteria tertentu. Folger dan Konovsky (1986) menjelaskan bahwa keadilan distributif adalah keadilan yang dirasakan oleh karyawan berkaitan dengan kompensasi yang diterima.

Keadilan prosedural adalah keyakinan mengenai evaluasi kinerja yang adil dapat berdasarkan dari prosedur dimana evaluasi ditentukan dan tidak ada hubungannya terhadap peringkat yang diterima (Giri, 2014). Leventhal (1980) mendefinisikan keadilan prosedural sebagai proses pengalokasian sumber daya sudah dilakukan dengan tepat dan adil sesuai kriteria tertentu.

$$
\text { Locke et al }
$$
menjelaskan bahwa komitmen tujuan adalah tingkat komitmen dalam diri individu untuk mencapai tujuan tertentu dan merupakan faktor utama dalam teori penetapan tujuan. Komitmen tujuan anggaran adalah komitmen yang digunakan untuk mencapai sasaran atau tujuan (Giri, 2014). Definisi tersebut mengartikan bahwa manajer yang memiliki komitmen tujuan yang tinggi dalam dirinya memiliki keyakinan yang baik 
dan berusaha untuk mencapai tujuan anggaran.

Penelitian ini menguji pengaruh partisipasi anggaran terhadap kinerja manajerial, dan pengaruh keadilan distributif penganggaran, keadilan prosedural penganggaran, dan komitmen tujuan anggaran terhadap hubungan antara partisipasi anggaran dengan kinerja manajerial pada Universitas Diponegoro. Universitas Diponegoro merupakan salah satu perguruan tinggi negeri negeri terbaik di Indonesia dan memiliki akreditasi yang baik. Universitas diponegoro juga salah satu dari sepuluh perguruan tinggi di Indonesia yang masuk ke dalam peringkat $Q S$ World.

Universitas

Diponegoro

sebagai perguruan tinggi negeri yang menerapkan Pengelola Keuangan Badan Layanan Umum (PK - BLU) secara penuh. Surat Nomor 85/MPN/KU/2008 menjelaskan bahwa Menteri Pendidikan Nasional mengajukan permohonan kepada Kementerian Pendidikan Nasional agar Universitas Diponegoro ditetapkan sebagai instansi pemerintah yang menerapkan PK - BLU. Penetapan Universitas Diponegoro sebagai PK - BLU secara penuh memiliki arti bahwa Universitas Diponegoro diberikan fleksibilitas dalam mengelola keuangan sesuai dengan Peraturan Pemerintah No 23 Tahun 2005 tentang Pengelolaan Keuangan Badan Layanan Umum dan peraturan pelaksanaannya.

Dengan

diberikannya

fleksibilitas pengelolaan keuangan membuat Universitas Diponegoro dapat menyusun anggaran sesuai dengan target yang ingin dicapai dan hal itu akan berpengaruh terhadap kinerja manajerial. Dengan fleksibilitas itu pula, maka perlu dipertanyakan persepsi keadilan distributif serta prosedural penganggaran yang akan mempengaruhi penyusunan anggaran dengan kinerja manajerial yang pada akhirnya akan mempengaruhi mutu, sistem dan layanan pendidikan Universitas Diponegoro. Jika mutu, sistem, dan layanan kurang baik maka akan mempengaruhi akreditasi.

Berdasarkan

keputusan

Direktur Pembinaan Pengelolaan Keuangan Badan Layanan Umum (BLU), Kementrian Keuangan, Nomor KEP 201/PB.5/2013 tentang penetapan hasil penilaian kinerja Badan Layanan Umum bidang pendidikan tahun 2012 tanggal 31 
Desember 2013

menempatkan

Universitas

Diponegoro

pada

peringkat ke-2 dari 22 Perguruan

Tinggi Negeri Pengelola Keuangan

Badan Layanan Umum (PK-BLU)

bidang pendidikan. Penilaian PK-BLU terdiri dari dua aspek, yaitu aspek keuangan dan aspek layanan. Salah satu penilaian dari PK-BLU adalah aspek penyusunan Rencana Anggaran dan Bisnis (RBA), sedangkan penilaian aspek layanan meliputi kualitas pelayanan pendidikan, mutu, dan manfaat kepada masyarakat. Skor aspek keuangan sebesar 22.62, sedangkan skor aspek layanan sebesar 61.20, jadi total skor sebesar 83.82. Total skor tersebut membawa Universitas Diponegoro mendapat predikat AA-Baik. Menurut Soedartho (2014), prestasi tersebut merupakan pengakuan atas kinerja manajemen, khusunya pada bidang keuangan dan layanan, diharapkan dengan prestasi tersebut dapat terus mendorong bagian untuk meningkatkan kinerja manajemen menjadi lebih baik.

\section{TINJAUAN PUSTAKA DAN}

\section{PENGEMBANGAN HIPOTESIS}

\section{Teori Keadilan}

Adams merupakan orang yang pertama kali mengembangkan teori keadilan pada tahun 1963. Definisi dari teori keadilan adalah teori yang menjelaskan mengenai perbandingan yang dilakukan oleh pekerja mengenai apa yang mereka peroleh dengan apa yang mereka berikan terhadap organisasi (Robbins dan Judge, 2015). Teori keadilan menganggap bahwa motivasi seseorang dikaitkan dengan ekuitas (equity), dan keadilan (fairness dan justice) yang diterapkan oleh atasan.

Ikhsan dan Iskhak

berpendapat bahwa teori keadilan membandingkan masukan dan keluaran pekerjaan orang lain dengan masukan dan pekerjaan dirinya sendiri dan setelah itu terciptalah persepsi adil atau tidaknya dalam dirinya sendiri. Hal senada juga dituturkan oleh Adams yang menganggap bahwa teori keadilan berfokus kepada fokus relatif outcome yang didapatkan dengan input yang diberikan kepada perusahaan. Input yang dimaksud adalah segala kontribusi yang diberikan indidividu dalam pekerjaannya atau yang memiliki hubungan dengan pekerjaan. Input dapat berupa waktu, tenaga loyalitas, komitmen, kepercayaan kepada atasan, toleransi, dan lainnya. Sedangkan, outcome merupakan hasil 
yang diterima baik positif maupun negatif oleh karyawan akibat input yang diberikan. Outcome dapat berupa kompensasi, tanggung jawab, reputasi, pengakuan, promosi, dan lainnya (Giri, 2014).

Teori keadilan merupakan konsep utama keadilan organisasional, yaitu keadilan prosedural dan keadilan distributif (Hasniasari et al, 2014). Merujuk pada teori keadilan, keadilan prosedural dan keadilan distributif mengacu kepada persepsi karyawan terhadap kewajaran dan keseimbangan antara input yang mereka berikan kepada organisasi dengan outcome organisasional yang mereka terima, serta persepsi karyawan mengenai kewajaran proses-proses yang digunakan untuk mendistribusikan outcome organisasional (Pareke, 2004).

\section{Teori Penetapan Tujuan}

$$
\text { Menurut Sekaran }
$$

penetapan tujuan adalah proses yang mengikutsertakan atasan dan bawahan secara bersama-sama untuk menentukan atau menetapkan tujuan atau sasaran. Tujuan atau sasaran dapat ditambahkan dengan memberi penjelasan atau informasi keapada bawahan bagaimana melaksanakan tugas, serta mengapa tujuan atau sasaran tersebut penting untuk dilaksanakan (Soetrisno, 2010). Sekaran (1992) menuturkan bahwa penetapan tujuan atau sasaran yang dilakukan oleh manajemen untuk keberhasilan mencapai kinerja. Robbins dan Judge (2015:135) berpendapat bahwa teori penetapan tujuan adalah tujuan yang sulit, spesifik dan terdapat umpan balik akan menghasilkan kinerja yang tinggi. Penentuan tujuan yang spesifik dan menantang adalah sesuatu yang terbaik bagi karyawan untuk meningkatkan kinerja (Setiadi, 2013). Teori penetapan tujuan menjelaskan hubungan tujuan dengan kinerja. Semakin tinggi komitmen yang dimiliki untuk mencapai tujuan, maka semakin tinggi pula usaha seseorang sehingga dapat mempengaruhi kinerja. Soetrisno (2010) berpendapat bahwa teori penetapan tujuan yang mengikutsertakan manajer dalam partisipasi anggaran mempengaruhi harapan atas hasil yang diinginkan.

Locke (1981) berpendapat bahwa penetapan tujuan merupakan proses perilaku dari utilitas praktis. Artinya, keinginan dan tujuan individu merupakan pengukuran perilaku yang utama. Locke juga menggunakan 
keinginan dan tujuan untuk Kemungkinan keuntungan utama dari mengusulkan dan mendukung penelitian bahwa jika tujuan dapat diterima oleh individu, maka semakin kuat suatu tujuan akan menghasilkan kinerja yang tinggi (Locke, 1981)

Terdapat beberapa kasus yang menjelaskan bahwa tujuan-tujuan yang ditetapkan dengan cara partisipatif akan meningkatkan kinerja. Kasus-kasus lain juga menggambarkan saat manajer diberikan tujuan, maka mereka dapat bekerja dengan baik (Setiadi, 2013). partisipasi berada pada peningkatan penerimaan tujuan sebagai tujuan kita bekerja.

Syarat terjadinya penetapan tujuan yang efektif adalah harus adanya komitmen tujuan (Locke et al, 1988). Locke (1980) menggunakan adanya keingininan dan tujuan untuk mengusulkan dan mendukung penelitian bahwa semakin kuat tujuan yang ingin dicapai, maka akan menghasilkan kinerja yang tinggi jika tujuan tersebut diterima oleh individu.

\section{Gambar 1}

\section{Kerangka Pemikiran}

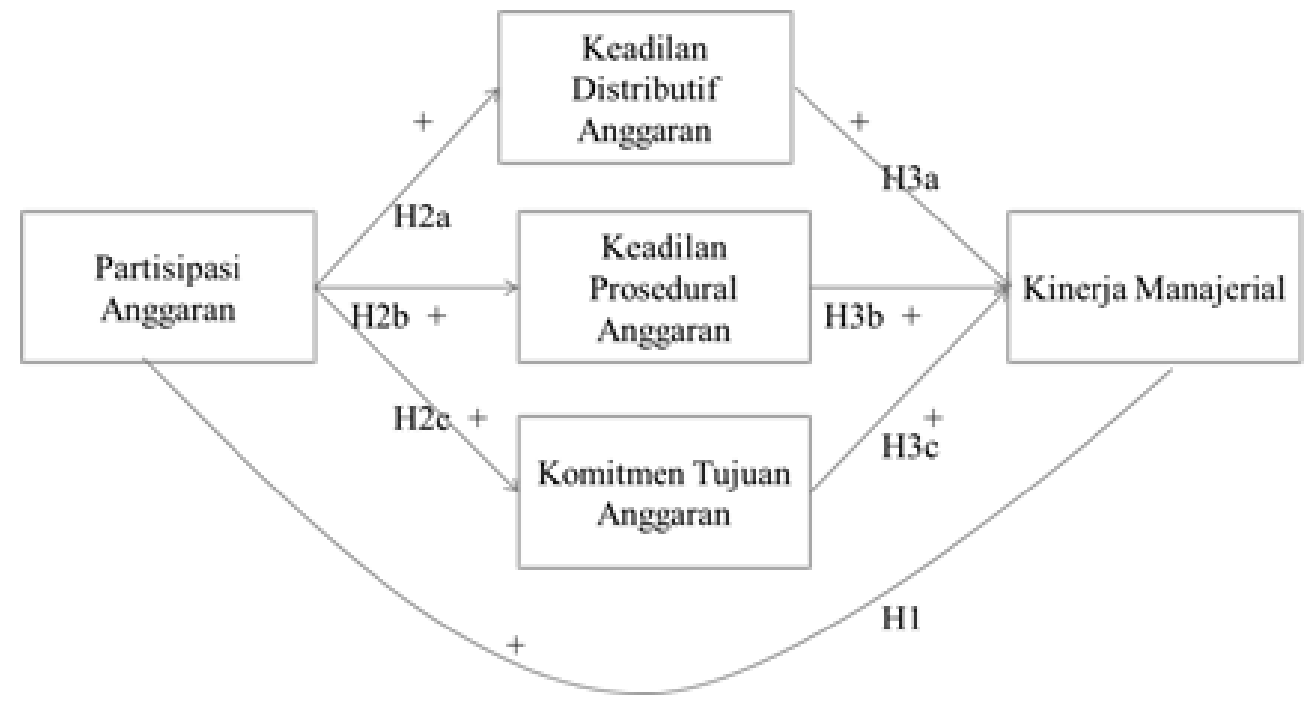

Partisipasi Anggaran dan Kinerja kinerja manajerial, yaitu teori penetapan Manajerial tujuan. Menurut Sekaran (1992) penetapan

Terdapat teori yang menjelaskan hubungan partisipasi anggaran dengan tujuan adalah proses yang mengikutsertakan atasan dan bawahan secara bersama-sama untuk penentuan atau penetapan tujuan atau 
sasaran. Dalam penetapan tujuan atau sasaran dapat diberikan penjelasan atau informasi kepada bawahan bagaimana melaksanakan tugas tersebut, serta mengapa tujuan atau sasaran tersebut penting untuk dilaksanakan (Sutrisno, 2010). Hal tersebut mengindikasikan bahwa adanya partisipasi bawahan dalam proses penganggaran. Dalam partisipasi anggaran, bawahan ikut bersamasama menentukan tujuan, sehingga ada rasa tanggung jawab dalam diri bawahan untuk mencapai tujuan tersebut dan diyakini dapat meningkatkan kinerja.

Partisipasi anggaran merupakan gabungan dari pendekatan top down dan bottom up (Halik, 2013). Manajer puncak tidak mengetahui dengan detail mengenai aktivitas yang terjadi di lapangan, sehingga harus mendapatkan informasi anggaran dari bawahannya. Tetapi, manajer puncak memiliki pandangan yang lebih luas mengenai organisasi, sehingga manajer puncak mengetahui hal-hal vital untuk menyusun anggaran. Setiap tingkatan tanggung jawab manajemen harus memberikan informasi terbaik sesuai dengan bidangnya dalam suatu sistem kerjasama partisipasi penyusunan anggaran (Giri, 2014). Partisipasi bawahan dalam penyusunan anggaran memiliki pengaruh yang positif terhadap motivasi manajerial dan akhirnya dapat berpengaruh terhadap peningkatan kinerja manajerial (Hasniasari dan Sholihin, 2014), karena keterlibatannya bawahan dalam penyusunan anggaran akan menghasilkan perturakaran infomasi yang efektif (Anthony dan Govindarajan, 2005).

Menurut Argyris (1952) jika bawahan terlibat dalam partisipasi anggaran maka akan meningkatkan kinerja. Partisipasi anggaran membuat seseorang merasa dihargai pendapatnya dan memiliki pengaruh dalam penyusunan anggaran, sehingga menjadikan seseorang bukan hanya bertanggung jawab, tetapi juga memiliki konsekuensi moral yang dapat meningkatkan kinerja sesuai dengan target anggaran (Halik, 2013). Hal yang senada juga dikemukakan oleh Giri (2014) bahwa partisipasi anggaran diharapkan dapat meningkatkan kinerja, karena suatu tujuan dirancang dan dalam partisipasi disetujui bersama, maka atasan dan bawahan akan menggabungkan dirinya dengan tujuan tersebut dan memiliki rasa tanggung jawab dalam dirinya untuk mencapainya karena terlibat dalam penyusunan anggaran. Greenberg dan Folger (1983) menyatakan bahwa partisipasi anggaran dapat meningkatkan kinerja, karena partisipasi memberikan kesempatan dan kemungkinan untuk bawahan mengkomunikasikan apa yang mereka butuhkan kepada atasan. Berdasarkan uraian diatas, maka hipotesis hubungan antara partisipasi anggaran dengan kinerja manajerial adalah: 
$\mathrm{H}_{1} \quad$ : Partisipasi anggaran berpengaruh positif terhadap kinerja manajerial

\section{Partisipasi Anggaran dan Persepsi Keadilan Anggaran}

Proses kontrol (partisipasi) yang dipengaruhi oleh berbagai keputusan dan konsekuensi dari hasil yang merata merupakan hal yang menentukan persepsi keadilan anggaran (Wentzel, 2002). Hubungan antara partsipasi anggaran dengan persepsi keadilan anggaran dihubungkan dengan teori self interest dan teori nilai kelompok (Wentzel, 2002).

Teori self interest menyatakan orang akan mencari keterlibatan dalam proses penganggaran karena mereka fokus terhadap keluaran mereka. Ketika bawahan diberikan kesempatan untuk berpartisipasi membuat mereka percaya bahwa masukan mereka memiliki peran untuk mencapai hasil yang diinginkan, oleh sebab itu persepsi keadilan meningkat. Sementara itu, Menurut teori nilai kelompok, orang akan menghargai hubungan jangka panjang dengan kelompoknya serta prosedur-prosedur yang dapat meningkatkan solidaritas kelompok. Partisipasi akan meningkatkan persepsi keadilan karena memungkinkan untuk mengekspresikan pandangan seseorang, dengan demikian hal itu merupakan kontribusi hubungan jangka panjang seseorang dengan kelompok (Wentzel, 2002)
Meningkatnya persepsi keadilan individu saat seseorang diberikan kesempatan untuk berpartisipasi karena mereka meyakini proses partisipasi tersebut penting untuk mencapai tujuan yang diharapkan (Hasniasari dan Sholihin, 2014). Hanny (2013) mengemukakan bahwa informasi yang diterima oleh karyawan dapat mengarahkan tingkat persepsi keadilan mereka. Partisipasi dalam penyusunan anggaran dapat meningkatkan persepsi keadilan karena karyawan beranggapan bahwa anggaran yang disetujui merupakan kesepakatan bersama dari sistem partisipasi anggaran (Hanny, 2013). Persepsi keadilan anggaran yang dimaksud adalah (1) keadilan distributif, yaitu yang melibatkan keadilan alokasi anggaran; (2) keadilan prosedural, yaitu yang melibatkan keadilan bagaimana alokasi anggaran yang diterima oleh karyawan (Magner dan Johnson, 1995; Ivancevich et al, 2008)

Menurut Yenti (2003), jika manajer terlibat dalam partisipasi anggaran, maka manajer terlibat dalam keputusan alokasi anggaran. Hal itu dapat disimpulkan bahwa partisipasi manajer dalam proses penganggaran dapat meningkatkan persepsi keadilan distributif serta prosedural. Hal itu dapat terjadi dikarenakan dalam proses penganggaran, manajer terlibat dalam proses penentuan alokasi anggaran, termasuk alokasi kompensasi dan cara bagaimana 
penentuan alokasi kompensasi diberikan kepada seluruh karyawan (Giri, 2014). Berdasarkan uraian diatas, dapat ditarik hipotesis sebagai berikut:

$\begin{array}{llr}\mathrm{H}_{2 \mathrm{a}} & : \quad \text { Partisipasi } & \text { anggaran } \\ & \text { berpengaruh positif terhadap } \\ & \text { keadilan } & \text { distributif } \\ & \text { penganggaran }\end{array}$

$\mathrm{H}_{2 \mathrm{~b}} \quad$ : Partisipasi anggaran berpengaruh positif terhadap keadilan prosedural penganggaran

\section{Partisipasi Anggaran dan Komitmen Tujuan Anggaran}

Dalam hubungan antara partisipasi anggaran dengan komitmen tujuan anggaran terdapat teori yang menjelaskan, yaitu teori penetapan tujuan. Sutrisno (2010) berpendapat bahwa penetapan tujuan yang mengikutsertakan manajer dalam partisipasi anggaran mempengaruhi harapan atas hasil yang diingiinkan. Terdapat beberapa kasus yang menjelaskan bahwa tujuan-tujuan yang ditetapkan dengan cara partisipatif akan meningkatkan kinerja. Kasus-kasus lain juga menggambarkan saat manajer diberikan tujuan, maka mereka dapat bekerja dengan baik (Setiadi, 2013). Kemungkinan keuntungan utama dari partisipasi berada pada peningkatan penerimaan tujuan sebagai tujuan kita bekerja.
Semakin banyak keterlibatan atau partisipasi dalam pembuatan keputusan membuat seseorang menjadi lebih mengenali organisasinya (Giri, 2014). Partisipasi dalam pembuatan keputusan mengintegrasikan pekerja untuk berkomitmen pada keputusan organisasi (Hasniasari dan Sholihin, 2014). Partisipasi akan meningkatkan kepercayaan bawahan, pengendalian, dan keterlibatan diri dengan organisasi, sehingga bawahan dapat menerima dan memiliki komitmen terhadap anggaran (Ayu dan Indarto, 2011). Damayanti (2007) mengemukakan bahwa keterlibatan bawahan dalam partisipasi anggaran akan dapat memupuk sikap mau menerima, berkomitmen yang lebih pada tujuan yang telah ditetapkan. Partisipasi membuat bawahan memiliki sikap mau bekerja sama dikarenakan mereka merasakan adanya keterlibatan (rasa memiliki), serta ikut merasakan menjadi bagian dari organisasi. Greenberg dan Folger (1983) menyatakan partisipasi memungkinkan bawahan untuk memilih, dan dalam memilih tersebut dapat membangun komitmen dan bertanggung jawab dengan apa yang dipilih.

$\mathrm{H}_{2 \mathrm{c}}$ : Partisipasi anggaran berpengaruh positif terhadap komitmen tujuan anggaran

Persepsi Keadilan Anggaran dan Kinerja Manajerial

Teori keadilan menjelaskan hubungan antara persepsi keadilan anggaran 
dengan kinerja manajerial. Teori keadilan menganggap bahwa motivasi seseorang dikaitkan dengan apa yang akan diperoleh, dan keadilan (fairness dan justice) yang diterapkan oleh atasan. Adams menganggap bahwa teori keadilan berfokus kepada fokus relatif outcome yang didapatkan dengan input yang diberikan kepada perusahaan (Giri, 2014). Input yang dimaksud adalah segala kontribusi yang diberikan indidividu dalam pekerjaannya atau yang memiliki hubungan dengan pekerjaan. Input dapat berupa waktu, tenaga loyalitas, komitmen, kepercayaan kepada atasan, toleransi, dan lainnya. Sedangkan, outcome merupakan hasil yang diterima oleh karyawan akibat input yang diberikan. Outcome dapat berupa kompensasi, tanggung jawab, reputasi, pengakuan, promosi, dan lainnya (Giri, 2014). Hal tersebut jika dikaitkan dengan hubungan antara persepsi keadilan anggaran dengan kinerja manajerial adalah ketika persepsi keadilan anggaran sudah tercipta dalam diri bawahan, maka mereka akan memberikan masukan untuk mencapai target-target anggaran dengan harapan bahwa mereka akan menerima keluaran sebagai apresiasi perusahaan kepada mereka. Persepsi keadilan dapat meningkatkan kinerja karena para partisipan menganggap dan percaya bahwa anggaran telah disusun serasional mungkin, sehingga dorongan dan motivasi yang mereka miliki meningkat untuk mencapai target anggaran (Hanny, 2013). Berdasarkan uraian diatas, maka dapat ditarik hipotesis sebagai berikut:

$\mathrm{H}_{3 \mathrm{a}} \quad$ : Keadilan distributif berpengaruh positif terhadap kinerja manajerial

$\mathrm{H}_{3 \mathrm{~b}} \quad$ : Keadilan prosedural berpengaruh positif terhadap kinerja manajerial

\section{Komitmen Tujuan Anggaran dan Kinerja}

\section{Manajerial}

Dalam hubungan komitmen tujuan anggaran dengan kinerja manajerial, terdapat teori pendukung yang dapat menjelaskan hal tersebut, yaitu teori penetapan tujuan. Teori penetapan tujuan menjelaskan hubungan tujuan dengan kinerja. Semakin tinggi komitmen yang dimiliki untuk mencapai tujuan, maka semakin tinggi pula usaha seseorang sehingga dapat mempengaruhi kinerja. Hal senada juga disampaikan oleh Locke bahwa penggunaan keinginan dan tujuan untuk mengusulkan dan mendukung penelitian bahwa jika tujuan dapat diterima oleh individu, maka semakin kuat suatu tujuan akan menghasilkan kinerja yang tinggi (Locke, 1981)

Magner et al (1996) mengemukakan bahwa bawahan yang memiliki komitmen tinggi pada tujuan anggaran akan melakukan interaksi dengan orang-orang yang memiliki wawasan mengenai lingkungan kerja, tujuan kinerja, strategi tugas, masalah-masalah lain yang memiliki tujuan pada kinerja. 
Tingginya komitmen tujuan terhadap penerimaan anggaran walaupun sesulit apapun tujuan anggaran dicapai, dengan demikian akan meningkatkan kinerja (Indarto dan Ayu, 2011). Berdasarkan uraian diatas, maka dapat ditarik hipotesis sebagai berikut:

$\mathrm{H}_{3 \mathrm{c}}$ : Kinerjaa tujuan anggaran berpengaruh positif terhadap kinerja manajerial

\section{METODE PENELITIAN}

\section{Populasi dan Sampel}

Populasi pada penelitian ini adalah seluruh pejabat yang terlibat dalam penyusunan anggaran di lingkungan Universitas Diponegoro. Sample dipilih dengan menggunakan teknik purposive sampling dengan responden kepala bagian, kepala sub bagian, ketua jurusan, ketua program studi, sekretaris jurusan, dan sekretaris program studi. Penelitian ini menggunakan jenis data primer dengan metode kuesioner dan wawancara. Kuesioner yang disebar sebanyak 189 buah tetapi hanya 72 kuesioner yang dapat diolah dengan 12 kuesioner merupakan data outlier.

\section{Variabel Penelitian Definisi Operasional Variabel}

Partisipasi anggaran merupakan keikutsertaan bawahan dalam menyusun rencana kegiatan organisasi yang diukur dalam ukuran finansial serta mereka yang terlibat memiliki pengaruh didalamnya. Pengukuran partisipasi anggaran menggunakan enam butir pertanyaan yang dikembangkan oleh Milani (1975) dan digunakan dalam penelitian Adrianto (2008), Giri (2014), dan Kohlmeyer (2014).

Kinerja manajerial adalah hasil dari tindakan dan perilaku seseorang atau sekelompok didalam organisasi. Pengukuran kinerja manajerial menggunakan sepuluh butir pertanyaan yang Adrianto (2008), Sutrisno (2010), Giri (2014).

Keadilan distributif penganggaran merupakan sumber penghasilan atau penghargaan dari perusahaan yang diberikan kepada karyawan. Skala untuk keadilan distributif terdiri dari lima butir pertanyaan yang menguji kewajaran anggaran dalam hal memenuhi kebutuhan dan harapan manajer. Instrumen pertanyaan mengadopsi dari penelitian Magner dan Johnson (1995) dan digunakan dalam penelitian Kohlmeyer et al (2014), Giri (2014), Hasniasari dan Sholihin (2014).

Keadilan prosedural penganggaran adalah rasa percaya dalam diri individu bahwa proses penyusunan anggaran sudah dilakukan secara adil. Keadilan yang dirasakan dari sistem anggaran dinilai menggunakan pengukuran yang dikembangkan oleh Magner dan Johnson (1995) dan setelah itu dimodifikasi oleh Wentzel (2002) yang melaporkan kehandalan 
yang memuaskan dan validitas. Pengukuran tersebut digunakan dalam penelitian diantaranya oleh Kohlmeyer et al (2014), Giri (2014), Hasniasari dan Sholihin (2014).

Menurut Locke (1981) komitmen tujuan aggaran adalah pengukuran seseorang untuk mencapai sasaran atau tujuan. Komitmen tujuan anggaran adalah motivasi, dan bulatnya tekat serta banyaknya usaha dalam mencapai tujuan. Terdapat tiga butir pertanyaan Latham dan Steele (1983) untuk mengukur komitmen tujuan anggaran. Pertanyaan tersebut diadopsi oleh Wentzel (2002), Giri (2014), Hasniasari dan Sholihin (2014).

Setiap pertanyaan-pertanyaan dari variabel independen diteliti menggunakan skala ordinal atau sering disebut skala likert (Ghozali, 2011), yaitu skala yang berisi tujuh tingkat preferensi jawaban (1 -7), nilai 1 diberikan apabila jawaban "sangat tidak setuju" dan nilai 7 apabila jawaban yang diberikan "sangat setuju".

\section{Metode Analisis}

Pengujian hipotesis dilakukan menggunakan teknik analisis jalur (path analysis) dengan menggunakan $\alpha=5 \%$ kaidah pengambilan keputusannya adalah :

1. Jika nilai probabilitas ( $\operatorname{sig})<\alpha=$ $5 \%$ maka hipotesis alternatif didukung.
2. Jika nilai probabilitas ( $\operatorname{sig})>\alpha=$ $5 \%$ maka hipotesis alternatif tidak didukung.

Persamaan regresi untuk pengujian menggunakan analisis jalur (path analysis) sebagai berikut:

$$
\begin{aligned}
& \mathrm{Y}_{\mathrm{KD}}=\mathrm{b}_{\mathrm{o}}+\mathrm{b}_{\mathrm{PA}} \mathrm{X}_{\mathrm{PA}}+\mathrm{e}_{1} \\
& \mathrm{Y}_{\mathrm{KP}}=\mathrm{b}_{\mathrm{o}}+\mathrm{b}_{\mathrm{PA}} \mathrm{X}_{\mathrm{PA}}+\mathrm{e}_{2} \\
& \mathrm{Y}_{\mathrm{KTA}}=\mathrm{b}_{\mathrm{O}}+\mathrm{b}_{\mathrm{PA}} \mathrm{X}_{\mathrm{PA}}+\mathrm{e}_{3} \\
& \mathrm{Y}_{\mathrm{KM}}=\mathrm{b}_{\mathrm{o}}+\mathrm{b}_{\mathrm{PA}} \mathrm{X}_{\mathrm{PA}}+\mathrm{b}_{\mathrm{KD}} \mathrm{X}_{\mathrm{KD}}+\mathrm{b}_{\mathrm{KP}} \mathrm{X}_{\mathrm{KP}}+ \\
& \mathrm{b}_{\mathrm{KTA}} \mathrm{X}_{\mathrm{KTA}}+\mathrm{e}_{4}
\end{aligned}
$$

\section{HASIL PENELITIAN DAN \\ PEMBAHASAN}

\section{Gambaran Umum Responden}

Objek dalam penelitian ini adalah institusi pendidikan yang menerapkan Pengelola Keuangan Badan Layanan Umum (PK-BLU) oleh pemerintah dan salah satu dari sepuluh perguruan tinggi di Indonesia yang masuk kedalam peringkat $Q S$ World, yaitu Universitas Diponegoro. Responden dalam penelitian ini adalah kepala bagian, kepala subbagian, ketua serta sekretaris jurusan dan program studi. Dipilihnya kepala bagian, kepala subbagian, ketua serta sekretaris jurusan dan program studi sebagai responden adalah karena mereka memiliki peran penting dalam penyusunan anggaran. Rencana kegiatan yang disusun dalam anggaran akan berpengaruh pada kinerja manajerial. Penyebaran kuesioner dimulai dari tanggal 4 Januari 2016, sedangkan waktu 
pengembalian dan pengumpulan kuesioner paling lambat tanggal 20 Januari 2016. Dalam menyebarkan kuesioner, penulis mendatangi langsung objek dan responden penelitian. Berikut ini adalah daftar kepala bagian, kepala subbagian, ketua serta sekretaris jurusan dan program studi di Universitas Diponegoro yangdijadikan sebagai dan daftar kuesioner yang disebar:

Tabel 1

Daftar Unit Bagian

\begin{tabular}{|c|c|c|c|}
\hline No & Nama Unit Bagian & Jumlah Kuesioner & $\begin{array}{l}\text { Jumlah yang } \\
\text { Kembali }\end{array}$ \\
\hline 1 & Fakultas Ekonomika dan Bisnis & 21 & 6 \\
\hline 2 & Fakultas Ilmu Sosial dan Ilmu Politik & 21 & 6 \\
\hline 3 & Fakultas Psikologi & 5 & 4 \\
\hline 4 & Fakultas Hukum & 7 & 4 \\
\hline 5 & Fakultas Ilmu Budaya & 5 & 3 \\
\hline 6 & Fakultas Kedokteran & 5 & 3 \\
\hline 7 & Fakultas Kesehatan Masyarakat & 7 & 4 \\
\hline 8 & Fakultas Perikanan dan Ilmu Kelautan & 11 & 7 \\
\hline 9 & Fakultas Teknik & 12 & 3 \\
\hline 10 & Fakultas Sains dan Matematika & 15 & 5 \\
\hline 11 & Fakultas Peternakan dan Pertanian & 9 & 4 \\
\hline 12 & Program Pasca Sarjana & 3 & 1 \\
\hline 13 & $\begin{array}{l}\text { Lembaga Pengembangan dan Penjamin Mutu } \\
\text { Pendidikan }\end{array}$ & 3 & 3 \\
\hline 14 & $\begin{array}{l}\text { Lembaga Pengembangan dan Penjamin Mutu } \\
\text { Pendidikan }\end{array}$ & 8 & 3 \\
\hline 15 & Lembaga Pengadaan Secara Elektronik & 2 & 2 \\
\hline 16 & $\begin{array}{l}\text { Biro Administrasi Perencanaan dan Sistem } \\
\text { Informasi }\end{array}$ & 8 & 3 \\
\hline 17 & Biro Administrasi Akademik & 8 & 4 \\
\hline 18 & Biro Administrasi Kemahasiswaan & 8 & 6 \\
\hline 19 & Biro Administrasi Umum dan Keuangan & 11 & 8 \\
\hline 20 & UPT Pusat Komputer & 2 & - \\
\hline 21 & UPT Perpustakaan & 2 & 2 \\
\hline 22 & UPT Undip Inpress & 2 & 2 \\
\hline 23 & UPT Laboraturium & 2 & - \\
\hline 24 & Undip Career Center & 1 & 1 \\
\hline 25 & Rumah Susun Mahasiswa & 3 & 1 \\
\hline 26 & Rumah Sakit Nasional Diponegoro & 8 & - \\
\hline \multicolumn{2}{|c|}{ Total } & 189 & 85 \\
\hline \multicolumn{2}{|c|}{ Jumlah Kuesioner yang tidak lengkap } & - & $(13)$ \\
\hline \multicolumn{2}{|c|}{ Jumlah Kuesioner yang dapat digunakan } & - & 72 \\
\hline
\end{tabular}

Sumber : Data primer yang diolah, 2016

Dapat dilihat pada tabel di atas

bahwa kuesioner yang dibagikan adalah

189 kuesioner. Kuesioner yang dikembalikan oleh para responden adalah 85 kuesioner (44,97\%), kuesioner yang tidak kembali sejumlah 104 kuesioner 
$(55,02 \%)$, kuesioner yang tidak lengkap sebanyak 13 kuesioner (6,87\%). Dalam melakukan olah data, terdapat data outlier yang menyimpang terlalu jauh dari data lainnya yang menjadikan hasil data menjadi bias dan dapat mencerminkan hasil yang tidak sebenarnya sehingga data outlier tersebut tidak digunakan dalam analisis data. Terdapat 12 data outlier dalam penelitian ini sebesar atau sebesar $6,35 \%$. Sehingga jumlah kuesioner yang digunakan untuk penelitian ini sebanyak 60 kuesioner $(31,74 \%)$.

\section{Statistik Deskriptif}

Tujuan penyajian statistik deskriptif adalah untuk menggambarkan dan menjelaskan karakter sampel dalam penelitian serta memberikan deskripsi variabel yang digunakan dalam penelitian tersebut.Berikut ini adalah tabel hasil uji statistik:

Tabel 2

Statistik Deskriptif Variabel Penelitian

\begin{tabular}{|c|c|c|c|c|c|c|c|}
\hline \multirow[t]{2}{*}{ Variabel } & \multicolumn{2}{|c|}{ Kisaran Teoritis } & \multirow[t]{2}{*}{ Mean } & \multicolumn{2}{|c|}{$\begin{array}{l}\text { Kisaran } \\
\text { Sesungguhnya }\end{array}$} & \multirow[t]{2}{*}{ Mean } & \multirow[t]{2}{*}{ Std. Dev } \\
\hline & Min & Max & & Min & Max & & \\
\hline PA & 6 & 42 & 24 & 6 & 42 & 32,120 & 5,938 \\
\hline KD & 5 & 35 & 20 & 7 & 35 & 26,650 & 5,207 \\
\hline KP & 8 & 56 & 32 & 16 & 53 & 42,520 & 7,797 \\
\hline KTA & 3 & 21 & 12 & 6 & 21 & 18,150 & 3,140 \\
\hline KM & 10 & 70 & 40 & 38 & 67 & 54,250 & 7,231 \\
\hline
\end{tabular}

Sumber : Data primer yang diolah, 2016

Pada tabel 2 menunjukkan bahwa hasil pengukuran statistik deskriptif terhadap variabel dari 60 responden.Variabel partisipasi anggaran (PA) terdiri dari 6 buah pertanyaan pada skala likert 7 poin.Adapun kisaran jawaban responden (kisaran sesungguhnya) sebesar 6 sampai dengan 72 dimana kisaran teoritisnya adalah 6 sampai dengan 30. Nilai mean partisipasi anggaran sebesar 32,120 dan standar deviasi 5,938. Nilai mean jawaban variabel partisipasi anggaran untuk kisaran sesungguhnya lebih besar dibandingkan dengan nilai mean kisaran teoritis. Hal ini mengindikasikan tingkat partisipasi anggaran yang relatif tinggi.Selain itu, standar deviasi yang relatif rendah yaitu sebesar 5,938 menunjukkan bahwa variasi jawaban yang diberikan oleh responden untuk pengukuran variabel partisipasi anggaran relatif kecil.

Variabel persepsi keadilan distributif anggaran (KD) mempunyai nilai kisaran teoritis sebesar 5 sampai dengan 35 dengan nilai mean 20. Sedangkan pada kisaran 
sesungguhnya, persepsi keadilan distributif anggaran (KD) mempunyai nilai kisaran sesungguhnya sebesar 7 sampai 35 dengan nilai mean 26,650 dan standar deviasi sebesar 5,207. Nilai mean atas jawaban persepsi keadilan distributif anggaran (KD) untuk nilai kisaran sesungguhnya diatas nilai mean kisaran teoritis. Hal itu mengindikasikan bahwa tingkat persepsi keadilan distributif yang dimiliki relatif tinggi.Nilai standar deviasi variabel persepsi keadilan distributif anggaran memiliki variasi jawaban yang diberikan oleh responden relatif kecil.

Variabel persepsi keadilan prosedural anggaran (KP) memiliki nilai kisaran teoritis sebesar 8 sampai dengan 56 dengan nilai mean 32. Sedangkan pada kisaran sesungguhnya, persepsi keadilan prosedural anggaran (KP) mempunyai nilai kisaran sesungguhnya sebesar 16 sampai dengan 53 dengan nilai mean 42,520 dan nilai standar deviasi 7,797. Nilai mean atas jawaban persepsi keadilan prosedural anggaran (KP) untuk nilai kisaran sesungguhnya diatas nilai mean kisaran teoritis. Hal itu mengindikasikan bahwa tingkat persepsi keadilan prosedural yang dimiliki relatif tinggi. Nilai standar deviasi variabel persepsi keadilan prosedural anggaran lebih tinggi dibandingkan dengan variabel lainnya, yaitu sebesar 7,797 yang menunjukkan bahwa variasi jawaban yang diberikan responden untuk pengukuran variabel ini relatif tinggi
Variabel komitmen tujuan anggaran (KTA) memiliki nilai kisaran teoritis sebesar 3 sampai dengan 21 dengan nilai mean 12 . Sedangkan pada kisaran sesungguhnya, komitmen tujuan anggaran (KTA) memiliki nilai kisaran sesungguhnya sebesar 6 sampai dengan 21 dengan nilai mean 18,150 dan nilai standar deviasi 3,140. Nilai mean atas jawaban komitmen tujuan anggaran (KTA) untuk nilai kisaran sesungguhnya diatas nilai mean kisaran teoritis. Hal itu mengindikasikan bahwa tingkat komitmen tujuan anggaran yang dimiliki relatif tinggi.Nilai standar deviasi variabel komitmen tujuan anggaran memiliki variasi jawaban yang diberikan oleh responden relatif kecil.

Variabel kinerja manajerial (KM) memiliki nilai kisaran teoritis sebesar 10 sampai dengan 70 dengan nilai mean 40 . Sedangkan pada kisaran sesungguhnya, komitmen tujuan anggaran (KTA) memiliki nilai kisaran sesungguhnya sebesar 38 sampai dengan 67 dengan nilai mean 54,250 dan nilai standar deviasi 7,231. Nilai mean atas jawaban kinerja manajerial (KM) untuk nilai kisaran sesungguhnya diatas nilai mean kisaran teoritis. Hal itu mengindikasikan bahwa tingkat kinerja manajerial yang dimiliki relatif tinggi.Nilai standar deviasi variabel kinerja manaerial memiliki variasi jawaban yang diberikan oleh responden relatif kecil. 
Pada tabel 3 sampai dengan 6 akan ditunjukkan tabulasi silang dari setiap variabel independen terhadap variabel dependen. Berikut hasilnya.

Tabel 3

Tabulasi Silang Partisipasi Anggaran terhadap Keadilan Distributif, Keadilan Prosedural, Komitmen Tujuan Anggaran dan Kinerja Manajerial

\begin{tabular}{lllll}
\hline PA & KM & KD & KP & KTA \\
\hline 0 & 49,150 & 24,120 & 39,875 & 16,520 \\
1 & 57,885 & 28,457 & 44,277 & 19,314 \\
\hline
\end{tabular}

Sumber : Data primer yang diolah, 2016

Berdasarkan tabel 3 dapat dilihat bahwa nilai rata-rata Partisipasi Anggaran (PA) dibawah nilai rata-rata Kinerja Manajerial (KM) adalah 49,150. Sedangkan, nilai rata-rata Partisipasi Anggaran (PA) diatas nilai rata-rata Kinerja Manajerial (KM) adalah 57,885. Selain itu, nilai rata-rata responden yang menjawab Partisipasi Anggaran (PA) dibawah nilai rata-rata Keadilan Distributif (KD) adalah 24,120. Partisipasi Anggaran (PA) diatas nilai ratarata Keadilan Distributif (KD) adalah 28,457. Partisipasi Anggaran (PA) dibawah nilai Nilai rata-rata responden yang menjawab nilai rata-rata responden yang menjawab

rata-rata Keadilan Prosesural (KP) adalah 39,875. Kemudian, Nilai rata-rata Partisipasi Anggaran (PA) diatas nilai rata-rata Keadilan Prosedural (KP) adalah 44,277. Tabel 4.4 juga menunjukkan bahwa nilai rata-rata Partisipasi Anggaran (PA) dibawah nilai rata-rata Komitmen Tujuan Anggaran (KTA) adalah 16,520. Nilai rata-rata Partisipasi Anggaran (PA) diatas nilai rata-rata Komitmen Tujuan Anggaran (KTA) adalah 19,314 .

Tabel 4

Tabulasi Silang Keadilan Distributif terhadap Kinerja Manajerial

\begin{tabular}{ll}
\hline KD & KM \\
\hline 0 & 50,480 \\
1 & 56,942 \\
\hline
\end{tabular}

Sumber : Data Primer yang diolah, 2016

Tabel 4 menunjukkan bahwa nilai adalah 50,480. Sedangkan, nilai rata-rata Keadilan Distributif (KD) diatas nilai ratarata Kinerja Manajerial (KM) adalah 56,942. 
Tabel 5

Tabulasi Silang Keadilan Prosedural terhadap Kinerja Manajerial

\begin{tabular}{ll}
\hline KP & KM \\
\hline 0 & 50,681 \\
1 & 56,315 \\
\hline
\end{tabular}

Sumber : Data primer yang diolah, 2016

Berdasarkan tabel 5 dapat dilihat nilai rata-rata Keadilan Prosedural (KP) bahwa nilai rata-rata Keadilan Prosedural diatas nilai rata-rata Kinerja Manajerial (KP) dibawah nilai rata-rata Kinerja (KM) adalah 56,315.

Manajerial (KM) adalah 50,681. Sedangkan,

Tabel 6

Tabulasi Silang Komitmen Tujuan Anggaran terhadap Kinerja Manajerial

\begin{tabular}{ll}
\hline KTA & KM \\
\hline 0 & 50,968 \\
1 & 58,000 \\
\hline
\end{tabular}

Sumber : Data Primer yang diolah, 2016

Berdasarkan tabel 6 terlihat bahwa

\section{Pengujian Hipotesis}

nilai rata-rata Komitmen Tujuan Anggaran

Penelitian ini terdiri dari 7 hipotesis (KTA) dibawah nilai rata-rata Kinerja Manajerial (KM) adalah 50,968.

Sedangkan, nilai rata-rata Komitmen

Tujuan Anggaran (KTA) diatas nilai ratarata Kinerja Manajerial (KM) adalah 58,000 . yang diuji dengan menggunakan analisis jalur (path analysis). Pengujian hipotesis dilakukan untuk menganalisis pengaruh partisipasi anggaran terhadap kinerja manajerial dengan persepsi keadilan anggaran dan komitmen tujuan anggaran sebagai variabel intervening. Hasil pengujian adalah sebagai berikut : 
Tabel 7

\section{Hasil Pengujian Hipotesis}

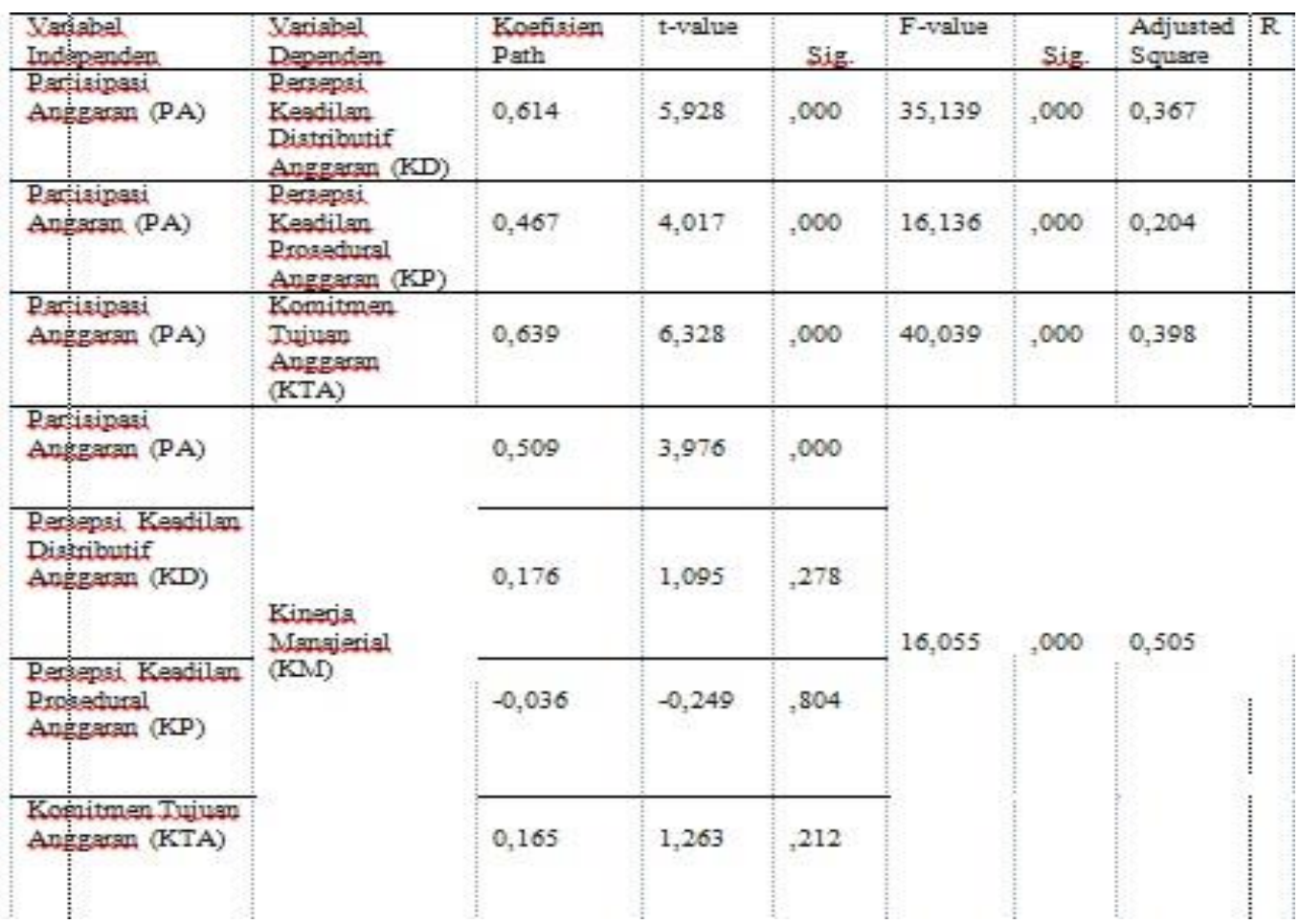

Sumber : Data primer yang diolah, 2016

\section{Pengaruh Partisipasi Anggaran terhadap}

Persepsi Keadilan Distributif Anggaran

Pada tabel 7 dapat dilihat hasil uji persamaan regresi 1 yang digunakan untuk menganalisis pengaruh partisipasi anggaran terhadap persepsi keadilan distributif anggaran menunjukkan nilai adjusted $\mathrm{R}^{2}$ sebesar 0,367 atau $36,7 \%$. Hasil uji signifikansi parameter (t-test) pada persamaan regresi 1 menunjukkan nilai sebesar 5,928 dengan nilai signifikansi 0,000. Hipotesis $\mathrm{H} 2 \mathrm{a}$ pada persamaan regresi 1 diterima. Keterlibatan aktif bawahan dalam penyusunan anggaran membuat para bawahan menerima alokasi anggaran yang sesuai dengan target yang ingin dicapai. Didalam partisipasi anggaran, jika pencapaian target anggaran merupakan hasil yang akan dicapai, dan usaha serta kemampuan untuk mencapai target anggaran merupakan masukan untuk mencapai hasil. Saat kemampuan dan usaha dicocokan dengan tingkat pencapaian anggaran, maka hal itu dapat terjadinya keadilan distributif. Keterlibatan bawahan dalam penentuan alokasi anggaran membuat peningkatkan persepsi keadilan distributif anggaran. Pemberian alasan yang logis oleh atasan mengenai anggaran yang direvisi serta adanya diskusi yang dilakukan oleh bawahan 
kepada atasan dapat meningkatkan persepsi keadialan distributif anggaran karena bawahan memiliki informasi bagaimana anggaran tersebut didistribusikan. Hal ini sejalan dengan Teori self interest menyatakan orang akan mencari keterlibatan dalam proses penganggaran karena mereka fokus terhadap keluaran atau target. Ketika bawahan diberikan kesempatan untuk berpartisipasi membuat mereka percaya bahwa masukan mereka memiliki peran untuk mencapai hasil yang diinginkan, sehingga persepsi keadilan meningkat. Terlibatnya manajer dalam partisipasi anggaran tidak menjamin manajer akan mendapatkan anggaran yang diinginkan terutama saat terjadinya kelangkaan sumber daya, tetapi dengan terlibatnya manajer dalam partisipasi anggaran akan meningkatkan tentang bagaimana anggaran didistribusikan. Hasil yang ditunjukkan pada uji persamaan regresi 1 selaras dengan penelitian yang dilakukan oleh Wentzel (2002), Hanny (2013), Rofingatun et al (2013), Giri (2014).

\section{Pengaruh Partisipasi Anggaran terhadap} Persepsi Keadilan Prosedural Anggaran

Pada tabel 7 dapat dilihat hasil uji persamaan regresi 2 yang digunakan untuk menganalisis pengaruh partisipasi anggaran terhadap persepsi keadilan prosedural anggaran menunjukkan nilai adjusted $\mathrm{R}^{2}$ sebesar 0,204 atau 20,4\%. Hasil uji signifikansi parameter (t-test) pada persamaan regresi 2 menunjukkan nilai sebesar 4,017 dengan nilai signifikansi 0,000.Hipotesis $\mathrm{H} 2 \mathrm{~b}$ pada persamaan regresi 2 diterima.Keterlibatan aktif para bawahan dalam penyusunan anggaran dan diskusi yang dilakukan oleh bawahan kepada atasan mengenai pengusulan anggaran membuat keputusan anggaran didasarkan pada informasi yang akurat dan pendapat yang diinformasikan dengan baik. Pemberian alasan yang logis oleh atasan mengenai anggaran yang direvisi membuat atasan dalam mengambil keputusan anggaran tidak berpihak kepada salah satu lingkup tanggung jawab saja. Hal tersebut membuat prosedurprosedur dalam memutuskan anggaran yang dialokasikan dipersepsikan adil oleh bawahan.

Hasil penelitian ini sesuai dengan teori nilai kelompok, orang akan menghargai hubungan jangka panjang dengan kelompoknya serta prosedur-prosedur yang dapat meningkatkan solidaritas kelompok. Partisipasi akan meningkatkan persepsi keadilan prosedural karena memungkinkan untuk mengekspresikan pandangan seseorang, dengan demikian hal itu merupakan kontribusi hubungan jangka panjang seseorang dengan kelompok. Dari pengekspresian pandangan tersebut secara tidak langsung mereka memberikan 
informasi kepada yang lainnya sehingga penerimaan informasi yang diterima atau diberikan kepada karyawan dapat meningkatkan persepsi keadilan prosedural. Selain itu, Partisipasi dalam penyusunan anggaran dapat meningkatkan persepsi keadilan karena karyawan beranggapan bahwa anggaran yang disetujui merupakan kesepakatan bersama dari sistem partisipasi anggaran. Pendapat atau ide yang disampaikan oleh karyawan saat proses pengambilan keputusan dan/atau pada saat hasil keputusan meningkatkan persepsi individu mengenai keadilan prosedural. Pada sudut pandang ini, proses partisipatif yang memberikan kesempatan kepada individu untuk mengekspresikan pandangan mereka bahwa hasil keputusan adil karena menunjukkan bahwa mereka dihormati di tempat kerja yang berarti mereka diterima di kelompok sosial.Hasil yang ditunjukkan pada uji persamaan regresi 2 selaras dengan penelitian yang dilakukan oleh Wentzel (2002), Hanny (2013), Rofingatun et al (2013), Giri (2014).

\section{Pengaruh Partisipasi Anggaran terhadap}

\section{Komitmen Tujuan Anggaran}

Pada tabel 7 dapat dilihat hasil uji persamaan regresi 3 yang digunakan untuk menganalisis pengaruh partisipasi anggaran terhadap komitmen tujuan anggaran menunjukkan nilai adjusted $\mathrm{R}^{2}$ sebesar 0,398 atau $39,8 \%$. Hasil uji signifikansi parameter (t-test) pada persamaan regresi 3 menunjukkan nilai sebesar 6,328 dengan nilai signifikansi 0,000 . Hipotesis $\mathrm{H} 2 \mathrm{c}$ pada persamaan regresi 3 diterima.Berdasarkan dari jawaban yang diberikan oleh responden, keterlibatan aktif dalam penyusunan anggaran, pemberian alasan yang logis oleh atasan ketika anggaran direvisi dan adanya diskusi yang dilakukan oleh bawahan kepada atasan mengenai anggaran yang diusulkan membuat karyawan merasa bahwa target anggaran di dalam lingkup tanggung jawabnya merupakan hal yang penting untuk dicapai dan mereka berusaha untuk mencapai target anggaran.

Hal ini selaras dengan teori penetapan tujuan. Semakin banyak keterlibatan atau partisipasi dalam pembuatan keputusan membuat seseorang menjadi lebih mengenali organisasinya. Dengan mengetahui mengapa anggaran direvisi oleh atasan dan diskusi mengenai usulan anggaran akan menambah pengetahuan mereka mengenai apa yang sebenarnya terjadi dan hal tersebut membuat karyawan mengenali organisasinya. Saat seseorang mengenali organisasinya terdapat faktor psikis rasa memiliki terhadap organisasi sehingga timbul dalam diri bawahan bahwa target anggaran merupakan hal penting untuk dicapai dan berusaha keras untuk mencapainya. Selain itu, Partisipasi dalam pembuatan keputusan mengintegrasikan pekerja untuk 
berkomitmen pada keputusan organisasi. Keterlibatan aktif para bawahan dalam penyusunan anggaran akan meningkatkan kepercayaan bawahan, pengendalian, dan keterlibatan diri dengan organisasi, sehingga bawahan dapat menerima dan memiliki komitmen terhadap anggaran. Hasil yang ditunjukkan pada uji persamaan regresi 3 sesuai dengan penelitian yang dilakukan oleh Damayanti (2007), Indarto (2011), Hanny (2013), dan Giri (2014).

\section{Pengaruh Partisipasi Anggaran terhadap Kinerja Manajerial}

Pada tabel 7 dapat dilihat hasil uji persamaan regresi 4 yang digunakan untuk menganalisis pengaruh partisipasi anggaran terhadap kinerja manajerial melalui persepsi keadilan distributif anggaran, persepsi keadilan prosedural anggaran, dan komitmen tujuan anggaran menunjukkan nilai adjusted $\mathrm{R}^{2}$ sebesar 0,505 atau 50,5\%. Hasil uji signifikansi parameter (t-test) pada persamaan regresi 4 menunjukkan nilai sebesar 3,976 dengan nilai signifikansi 0,000. Hipotesis H1 pada persamaan regresi 4 diterima.Berdasarkan dari jawaban yang diberikan responden keterlibatan aktif para karyawan dalam penyusunan anggaran, adanya alasan yang logis dari atasan mengenai anggaran yang direvisi serta diskusi yang dilakukan oleh karyawan saat pengusulan anggaran membuat informasi yang didapatkan selama penyusunan anggaran digunakan bawahan untuk mengkoordinasikan laporan serta mengarahkan, memimpin, dan mengembangkan para bawahannya untuk bekerja sama dalam mencapai target anggaran. Adanya keterlibatan aktif para karyawan dalam penyusunan anggaran serta pemahaman informasi yang didapatkan dari atasan dan diskusi membuat para karyawan merealisasikan pekerjaannya sesuai dengan tujuan anggaran dan disesuaikan dengan target yang ingin dicapai. Pemahaman informasi ini membuat para karyawan memahami mengapa mereka harus mencapai target dan tujuan anggaran.

Hasil penelitian ini sesuai denga teori penetapan tujuan menyatakan bahwa proses yang mengikutsertakan atasan dan bawahan secara bersama-sama untuk penentuan atau penetapan tujuan atau sasaran. Partisipasi anggaran membuat seseorang merasa dihargai pendapatnya dan memiliki pengaruh dalam penyusunan anggaran, sehingga menjadikan seseorang bukan hanya bertanggung jawab, tetapi juga memiliki konsekuensi moral yang dapat meningkatkan kinerja sesuai dengan target anggaran (Supomo dan Nur, 1998). Hal yang senada juga dikemukakan oleh Milani (1975) bahwa partisipasi anggaran diharapkan dapat meningkatkan kinerja, karena suatu tujuan dirancang dan dalam partisipasi disetujui 
bersama, maka atasan dan bawahan akan menggabungkan dirinya dengan tujuan tersebut dan memiliki rasa tanggung jawab dalam dirinya untuk mencapainya karena terlibat dalam penyusunan anggaran. Hasil penelitian ini senada dengan hasil penelitian yang dilakukan oleh Frisilia (2007), Kamilah et al (2012), Budiman et al (2012), Halik (2013), Putra et al (2014).

\section{Pengaruh Persepsi Keadilan Anggaran terhadap Kinerja Manajerial}

Pada tabel 7 terdapat hasil yang berbeda ditunjukkan pada variabel persepsi keadilan distributif anggaran yang menunjukkan hasil uji signifikansi parameter (t-test) sebesar 1,095 dengan nilai signifikansi 0,278. Hal ini berarti bahwa variabel persepsi keadilan distributif anggaran tidak berpengaruh terhadap kinerja manajerial dan hipotesis $\mathrm{H} 3 \mathrm{a}$ ditolak.Hal yang sama juga ditemukan pada variabel persepsi keadilan prosedural anggaran yang menunjukkan hasil uji signifikansi parameter (t-test) sebesar $-0,249$ dengan nilai signifikansi 0,804. Hal itu menunjukkan bahwa variabel persepsi keadilan prosedural anggaran tidak berpengaruh terhadap kinerja manajerial dan hipotesis $\mathrm{H} 3 \mathrm{~b}$ ditolak.

Ditolak hipotesis H3a dan H3b adalah karena seluruh responden merupakan Pegawai Negeri Sipil (PNS) sehingga gaji atau tunjangan yang diterima oleh karyawan tidak banyak bergantung kepada hal tersebut dan usaha serta yang mereka berikan lebih cenderung menyesuaikan atau mengikuti distribusi dan prosedur yang ada. Disamping itu juga, pemberian penghargaan atau reward belum optimal dilakukan di lingkungan Universitas Diponegoro. Hasil penelitan ini tidak sesuai dengan teori keadilan yang menyatakan jika persepsi keadilan anggaran sudah tercipta dalam diri bawahan, maka mereka akan memberikan tenaga dan waktu lebih untuk mencapai target-target anggaran dengan harapan bahwa mereka akan menerima reward sebagai apresiasi perusahaan kepada mereka.Hasil uji persamaan regresi ini selaras dengan penelitian yang dilakukan oleh Yenti (2003) serta Khairan dan Ilham (2015).

\section{Pengaruh Komitmen Tujuan Anggaran terhadap Kinerja Manajerial}

Tabel 7 pada persamaan regresi 4 juga menunjukkan hasil yang berbeda pada variabel komitmen tujuan anggaran yang menunjukkan hasil uji signifikansi parameter (t-test) sebesar 1,263 dengan nilai signifikansi 0,212. Hal itu menunjukkan bahwa variabel komitmen tujuan anggaran tidak berpengaruh terhadap kinerja manajerial dan hipotesis $\mathrm{H} 3 \mathrm{c}$ juga mengalami penolakan.

Ditolaknya hipotesis H3c sesuai dengan teori penguatan yang menyatakan bahwa perilaku 
seseorang didasari oleh konsekuensi yang diberikan dan cenderung mengabaikan keadaan dalam dirinya. Komitmen merupakan hal yang ada didalam dirinya. Prinsip dari teori penguatan adalah setiap perilaku yang diikuti dengan konsekuensi positif atau menyenangkan akan ditingkatkan dan diperkuat serta cenderung diulang. Sebagai contoh pujian yang diberikan oleh atasan kepada karyawan karena pengumpulan tugas pekerjaan sebelum deadline dan hasil pekerjaannya baik atau pemberian hadiah jika perencanaan kerja direalisasikan semua dengan baik. Adanya konsekuensi terhadap perilaku karyawan menjadi faktor pengaruh peningkatan kinerja.Hasil penelitian ini sejalan dengan peneltian yang dilakukan oleh Yenti (2003).

\section{KESIMPULAN DAN SARAN}

Tujuan dari penelitian ini adalah untuk menguji pengaruh partisipasi anggaran terhadap kinerja manajerial pada Universitas Diponegoro dengan persepsi keadilan anggaran dan komitmen tujuan anggaran sebagai variabel intervening. Berdasarkan hasil pengujian dan analisis data, dapat diperoleh simpulan sebagai berikut:

1. Partisipasi anggaran berpengaruh positif terhadap kinerja manajerial yang berarti $\mathrm{H} 1$ diterima. Hasil penelitian ini selaras dengan penelitian yang dilakukan oleh
Frisilia (2007), Kamilah et al (2012), Budiman et al (2012), Halik (2013), Putra et al (2014).

2. Partisipasi anggaran tidak berpengaruh terhadap kinerja manajerial melalui persepsi keadilan distributif anggaran. Penelitian ini menunjukkan bahwa partisipasi anggaran berpengaruh positif terhadap persepsi keadilan distributif anggaran, tetapi persepsi keadilan distributif anggaran tidak berpengaruh terhadap kinerja manajerial yang berarti $\mathrm{H} 2 \mathrm{a}$ diterima, namun $\mathrm{H} 3 \mathrm{a}$ ditolak. Hasil penelitian ini menunjukkan bahwa persepsi keadilan distributif anggaran tidak dapat memediasi hubungan antara partisipasi anggaran dengan kinerja manajerial dan tidak sejalan dengan penelitian yang dilakukan Wentzel (2002) dan Giri (2014), tetapi sejalan dengan hasil penelitian Yenti (2003) serta Khairani dan Ilham (2015).

3. Partisipasi anggaran tidak berpengaruh terhadap kinerja manajerial melalui persepsi keadilan prosedural anggaran. Penelitian ini menunjukkan bahwa partisipasi anggaran berpengaruh positif terhadap persepsi keadilan prosedural anggaran, tetapi persepsi keadilan prosedural anggaran tidak 
berpengaruh terhadap kinerja manajerial yang berarti $\mathrm{H} 2 \mathrm{~b}$ diterima, namun $\mathrm{H} 3 \mathrm{~b}$ ditolak. Hasil penelitian ini menunjukkan bahwa persepsi keadilan prosedural anggaran tidak dapat memediasi hubungan antara partisipasi anggaran dengan kinerja manajerial dan tidak sejalan dengan penelitian yang dilakukan Rofingatun (2013) dan Giri (2014), tetapi sejalan dengan hasil penelitian Yenti (2003) serta Khairani dan Ilham (2015).

4. Partisipasi anggaran tidak berpengaruh terhadap kinerja manajerial melalui komitmen tujuan anggaran. Penelitian ini menunjukkan bahwa partisipasi anggaran berpengaruh positif terhadap komitmen tujuan anggaran, tetapi komitmen tujuan anggaran tidak berpengaruh terhadap kinerja manajerial yang berarti $\mathrm{H} 2 \mathrm{c}$ diterima, namun $\mathrm{H} 3 \mathrm{c}$ ditolak. Hasil penelitian ini menunjukkan bahwa komitmen tujuan anggaran tidak dapat memediasi hubungan antara partisipasi anggaran dengan kinerja manajerial dan tidak sejalan dengan penelitian yang dilakukan Indarto (2011), Giri (2014), Oktivani (2014), serta Khairani dan Ilham (2015) tetapi sejalan dengan hasil penelitian Yenti (2003).
Dalam melakukan penelitian ini terdapat keterbatasan yang dimiliki yang membatasi kesempurnaannya. Keterbatasan dalam penelitian ini antara lain:

1. Dalam penelitian ini menggunakan tiga variabel intervening yang memediasi hubungan partisipasi anggaran dan kinerja manajerial yaitu persepsi keadilan distributif anggaran, persepsi keadilan prosedural anggaran, dan komitmen tujuan anggaran. Dari hasil penelitian yang menunjukkan bahwa variabelvariabel tersebut tidak bisa memediasi hubungan antara partisipasi anggaran dan kinerja manajerial, maka diduga terdapat faktor-faktor lain yang memediasi hubungan partisipasi anggaran dan kinerja manajerial khususnya pada universitas.

2. Peneliti hanya melakukan wawancara pada beberapa responden dari unit bagian yang berbeda, sehingga tidak bisa mengeneralisasikan kondisi yang sebenarnya terjadi pada semua unit bagian di Universitas Diponegoro

3. Dalam melakukan penyebaran dan pengambilan kuesioner terdapat kendala untuk menemui responden, sehingga banyak data yang banyak terkumpul pada unit bagian tertentu saja. 
Dengan beberapa keterbatasan yang sudah disebutkan sebelumnya, penelitian selanjutnya diharapkan dapat mengatasinya. Berikut ini disampaikan beberapa saran untuk penelitian selanjutnya:

1. Dalam penelitian selanjutnya juga diharapkan dapat memperluas variabel-variabel lain yang relevan dan baik terkait kinerja manajerial, misalnya ketersediaan sumber daya, motivasi, budaya organisasi, kebijakan organisasi, dan perilaku kelompok kerja.

2. Penelitian selanjutnya diharapkan melakukan wawancara pada responden di setiap bagian agar dapat mengeneralisasi kondisi yang sebenarnya terjadi di Universitas Diponegoro.

3. Dalam melakukan penyebaran dan pengambilan kuesioner diharapkan dapat memilih waktu yang tepat agar dapat menemui responden yang dituju. Membuat janji atau menghubungi melalui pesan pendek dapat dilakukan.

\section{DAFTAR PUSTAKA}

Adrianto, Yogi. 2008. Analisis Pengaruh Partisipasi Penyusunan Anggaran Terhadap Kinerja Manajerial dengan Kepuasan Kerja, Job Relevant Information sebagai variabel Intervening. Tesis. Universitas Diponegoro.
Anthony dan Govindarajan. 2005. Management Control System, Edisi 11, penerjemah: F.X. Kurniawan Tjakrawala, dan Krista. Penerbit Salemba Empat, Buku 2, Jakarta.

Argyris. 1952. Organizational Leadership dan Participation management. The Journal of Business. Vol. XXVII (January): 1-7.

Budiman et al. 2013. Pengaruh Partisipasi Penyusunan Anggaran terhadap Kinerja Manajerial dengan Gaya kepemimpinan, Motivasi, dan Job Relevant Information sebagai Variabel Intervening.

Brownell, Peter. 1982. The Role of Accounting Data in Performance

Evaluation, Budgetary Participation, and Organizational Effectiveness. Journal of Accounting Research, Vol.20, No.1. pp. 16-27.

Chong, V.K. dan Chong, Kar Min. 2002. Budget Goal Commitment and Informational Effects of Budget Participation on Performance: A Structural Equation Modelling Approach. Behavioral Research in Accounting, Vol. 1, pp. 65-86.

Damayanti, Titien. 2007. Pengaruh Komitmen Anggaran dan Kultur Organisasional terhadap Hubungan Partisipasi Penganggaran dan Kinerja Manajerial pada Kondisi Stretch Target. Jurnal Akuntansi dan AuditingIndonesia, Vol.11, No.1, pp.81-101

Folger, R. dan Konovsky, M.A. 1989. Effect of Procedural and Distributive Justice on Reactions to Pay Raise Decisions. Academy ofManagement Journal, Vol.32, No.1, pp.115-130. 
Frisilia. 2007. Pengaruh Partisipasi Anggaran terhadap Kinerja Manajerial pada PT Cakra Compact Alumunium Industries.

Ghozali, I. 2011. Aplikasi Analisis Multivariate dengan SPSS. Badan Penerbitan Universitas Diponegoro.

Gibson, et al, 1995, Organisasi dan Manajemen, Edisi ke empat, Jakarta : Erlangga

Giri, Made. 2014. Pengaruh Partisipasi Anggaran terhadap Kinerja Manajerial dengan Keadilan Distributif, Keadilan Prosedural dan Komitmen Tujuan Anggaran sebagai Variabel Pemediasi.

Greenberg, J. 1986. Determinants of Perceived Fairness of Performance Evaluations. Journal of Applied Psychology, Vol.71, No.2, pp.340-342

Hafridebri. 2013. Pengaruh Partisipasi Anggaran terhadap Kinerja Manajerial melalui Komitmen Tujuan Anggaran dan Job Relevant Information sebagai Variabel Intervening pada Perusahaan Manufaktur di Pekanbaru.

Handoko, T. Hani. 1996. Manajemen. Edisi 2. Yogyakarta: BPFE.

Hanny. 2013. The Influence of Budgetary Participation on Managerial Performance at Banking Sector in Bandung and Cimahi City. InternationalConference on Business, Economics, and Accounting. BangkokThailand.

Hansen dan Mowen. 2009. Akuntansi Manajemen Edisi 8. Jakarta : Salemba Empat.

Hasniasari, R dan Sholihin, M. 2014. Analisis Hubungan Penganggaran Partisipatif dan Kinerja: Pengujian Efek Mediasi Keadilan Persepsian dan Komitmen pada Lembaga Hukum
Sektor Publik di Indonesia. Jurnal Akuntansi dan Keuangan, Vol. 16, No

Halik, Maria. 2013. Pengaruh Penyusunan Anggaran Partisipatif terhadap Kinerja Manajerial pada Perguruan Tinggi Swasta (Studi Empirik pada Perurguruan Tinggi Swasta Kopertis Wilayah IX Sulawesi. Skripsi. Universitas Hasanudin.

Herimawati, Rissa. 2013. Pengaruh Partisipasi Anggaran, Komitmen Organisasi dan Gaya Kepemimpinan terhadap Kinerja Manajerial pada PT Kusuma Dipa Nugraha. Skripsi. Universitas Pembangunan Nasional "Veteran" Jawa Timur.

Ikhsan, Arfan dan Muhammad Ishak. 2005. Akuntansi Keperilakuan. Jakarta : Salemba Empat.

Indarto dan Ayu. 2011. Pengaruh Partisipasi dalam Penyusunan Anggaran terhadap Kinerja Manajerial Perusahaan melalui Kecukupan Anggaran, Komitmen Organisasi, Komitmen Tujuan Anggaran, dan Job RelevantInformation (JRI). Seri Kajian Ilmiah, Vol. 14, No.1.

Kamilah et al. 2012. Pengaruh Partisipasi Anggaran Terhadap Kinerja Manajerial dengan Komitmen Organisasi dan Gaya Kepemimpinan sebagai Variabel Moderating. Jurnal Sorot, Vol. 8, No 2.

Khairani dan Ilham. 2015. Pengaruh Partisipasi Anggaran terhadap Kinerja Manajerial dengan Keadilan Distributif, Keadilan Prosedural, Komitmen Tujuan Anggaran, dan Job Relevant Information sebagai Variabel Intervening (Studi Empiris pada Perbankan di Kota Pekanbaru). 
Kohlmeyer et al. 2014. Leadership, Budget Participation, Budgetary Fairness, and Organizational Commitment. Advances in Accounting Behavioral Research, Vol 17, pp 95-118.

Kurnia, Ratnawati. 2010. Pengaruh Budgetary Goal Characteristics terhadap Kinerja Managerial dengan Budaya Paternalistik dan Komitmen Organisasi sebagai Moderating Variabel. Ultima Accounting, Vol. 2, No.2.

Latham dan Steele. 1983. The Motivational Effects of Participation Versus Goal Setting on Performance. Academy of Management. 406-417.

Locke, E.A., et al. 1981. Goal Setting and Task Performance: 1969-1980. Psycological Bulletin. Vol.90, No.1, pp.125-152.

Locke, E.A., G.P. Latham, dan M. Erez. 1988. The Determination of Goal Commitment. Academy of Management Review, Vol.13, No. 1, pp. 23-39.

Locke, E.A., Shaw K.N., Saari, L.M. dan Latham, G.P. 1981. Goal Setting and Task Performance: 1969 - 1980. Psychological Bulletin. Vol. 90, pp. $125-152$.

Magner, N. dan Johnson, G.G. 1995. Municipal Official's Reactions to Justice in Budgetary Resource. Public Administration Quarterly, Vol. 18, No.4, pp.439-456.

Maria, D. dan Nahartyo, E. 2012. Influence of Fairness Perception and Trust on Budgetary Slack: Study Experiment on Participatory Budgeting Context.
Simposium Nasional Akuntansi XVI. Banjarmasin

Medhayanti, N. dan Suardhana, K. 2015. Pengaruh Partisipasi Anggaran terhadap Kinerja Manajerial dengan Self Efficacy, Desentralisasi, dan Budaya Organisasi sebagai Variabel Pemoderasi.

Milani, K. 1975. The Relationship of Participation in Budget-Setting on

Industrial Supervisor Performance and Attitudes: A Field Study. The Accounting Review 50. April. pp.104123.

Mulyadi. 2001. Konsep Manfaat dan Rekayasa. Akuntansi manajemen. Jakarta: Salemba Empat.

Nor, Wahyudin. 2007. Desentralisasi dan Gaya Kepemimpinan Sebagai

Variabel Moderating Dalam Hubungan Antara Partisipasi Penyusunan Anggaran dan Kinerja Manajerial. Simposium Nasional Akuntansi X. Makasar.

Oktivani, Rani. 2014. Pengaruh Keadilan Distributif, Keadilan Prosedural, dan Komitmen Organisasi terhadap Kinerja Manajerial dalam Penyusunan Anggaran Pemerintah Kota Padang. Skripsi. Universitas Negeri Padang.

Pareke, F.J. 2004. Hubungan Keadilan dan Kepuasan dengan Keinginan Berpindah: Peran Komitmen Organisasional sebagai Variabel Pemediasi. JurnalSiasat Bisnis, Vol. 2, No. 9, pp.157-178.

Putra et al. 2014. Pengaruh Partisipasi dalam Penyusunan Anggaran terhadap Kinerja Manajerial pada SKPD Kabupaten Buleleng melalui Komitmen Organisasi, Kecukupan 
Anggaran, Komitmen Tujuan Anggaran, Job Relevant Information sebagai Variabel Moderating. e-jurnal S1 Ak Universitas Pendidikan Ganesha, Vol. 2, N0.1.

Qiftiyah, Mari'atul. Tujuan dan Manfaat Akreditasi Suatu Lembaga Pendidikan. $16 \quad$ November 2015. http://blog.umy.ac.id/mariatulqiftiyah/ tujuan-dan-manfaat-akreditasi-suatulembaga-pendidikan.

Republik Indonesia. 1945. Undang-Undang Dasar Negara Republik Indonesia tahun 1945, pasal 31. Jakarta

Robbins, Stephen P. dan Judge, T.A. 2008. Perilaku Organisasi (Organizational Behavior). Jakarta: Salemba Empat.

Rofingatun, Siti, et al. 2013. Effect of Budgeting Participation to Justice Organization, Organizational Commitment, and Organizational Performance in Papua Hospital. IOSR Journal of Business and Management, Vol.8, Issue 2, pp.1-6.

Sekaran, U. 1992. Research Methods for business: A skill Approach, John Wiley. New York.

Setiadi, Hidayat. 2013. Pengaruh Partisipasi Anggaran terhadap Kinerja Manajerial dengan Komitmen Organisasi dan Budget Emphasis sebagai Variabel Intervening (Studi Kasus pada SKPD Pemerintah Kabupaten Boyolali). Skripsi. Universitas Diponegoro.
Siegel, G. and Marconi, R. H. 1989. Behavioural Accounting. Ohio: SouthWestern Publishing Co.Cincinnati.

Soetrisno. 2010. Pengaruh Partisipasi, Motivasi, dan Pelimpahan Wewenang dalam Penyusunan Anggaran terhadap Kinerja Manajerial (Studi Empiris pada Dinas Daerah dan Lembaga Teknis Daerah di Kabupaten Rembang. Tesis. Universitas Diponegoro.

Sumadiyah dan Susanta. 2004. Job Relevant Information dan Ketidakpastian Lingkungan dalam Hubungan Partisipasi Penyusunan Anggaran dan Kinerja Manajerial. Simposium Nasional Akuntansi VII. Bali.

Supomo, B., dan Nur, Indriantoro. 1998. Pengaruh Struktur dan Kultur Organisasi terhadap Keefektifan Partisipasi Anggaran dalam Peningkatan Kinerja Manajerial: Studi Empiris pada Perusahaan Manufaktur. No.18: 61-68.

Wentzel, K. 2002. The Influence of Fairness Perceptions and Goal Commitment on Manager's Performance in a Budget Setting. BehavioralResearch in Accounting, Vol 12, pp.247-271.

Yenti, Riza Reni. 2003. Pengaruh Keadilan Distributif, Keadilan Prosedur, Komitmen terhadap Tujuan, dan Motivasi terhadap Kinerja Manajerial dalam Penyusunan Anggaran. Simposium Nasional Akuntansi VI. Surabaya. 